\title{
Delayed puberty - clinical approach and management
}

\author{
Pik To Cheung \\ From 8th APPES Biennial Scientific Meeting \\ Darwin, Australia. 29 October - 1 November 2014
}

Delayed puberty, while not uncommonly a variant of normal pubertal physiology, could be an indicator of a wide range of less common but important clinical disorders. Congenital pathologies may involve defective developments of the gonads, pituitary gonadotrophs or hypothalamic GnRH neurons. Acquired pathologies could likewise be acting at each level. Clinical diagnostic evaluation to delineate a good range of these disorders and the respective managements will be covered in this session.

Published: 28 April 2015

doi:10.1186/1687-9856-2015-S1-O20

Cite this article as: Cheung: Delayed puberty - clinical approach and

management. International Journal of Pediatric Endocrinology 20152015

(Suppl 1):O20.

The Unviersity of Hong Kong, Hong Kong, China

Submit your next manuscript to BioMed Central and take full advantage of:

- Convenient online submission

- Thorough peer review

- No space constraints or color figure charges

- Immediate publication on acceptance

- Inclusion in PubMed, CAS, Scopus and Google Scholar

- Research which is freely available for redistribution

Submit your manuscript at

www.biomedcentral.com/submit

\section{() Biomed Central}

(c) 2015 Cheung; licensee BioMed Central Ltd. This is an Open Access article distributed under the terms of the Creative Commons 